ENTREPRENEURSHIP AND SUSTAINABILITY ISSUES

ISSN 2345-0282 (online) http://jssidoi.org/jesi/

2020 Volume 8 Number 2 (December)

http://doi.org/10.9770/jesi.2020.8.2(62)
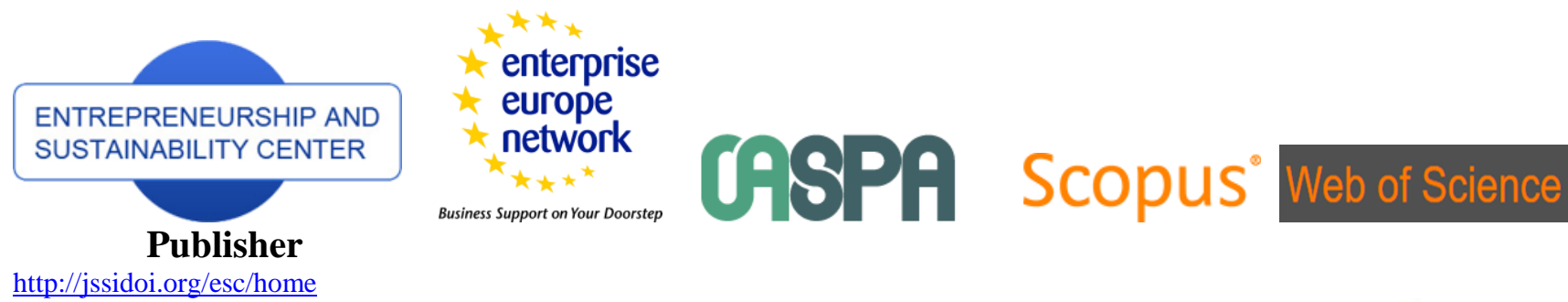

http://jssidoi.org/esc/home

Business Support on Your Doorstep
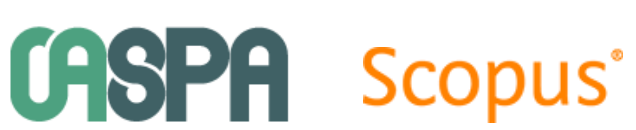

scopus

\title{
A MULTIOBJECTIVE CREDIBILISTIC PORTFOLIO SELECTION MODEL. EMPIRICAL STUDY IN THE LATIN AMERICAN INTEGRATED MARKET
}

\author{
Fernando García ${ }^{1}$, Jairo González-Bueno ${ }^{2}$, Francisco Guijarro ${ }^{3}$, Javier Oliver ${ }^{4}$ \\ ${ }^{1,4}$ Department of Economics and Social Sciences, Universitat Politècnica de València, Valencia, 46022, Spain \\ ${ }^{2}$ Faculty of Business Administration, Universidad Pontificia Bolivariana, Bucaramanga, 681017, Colombia \\ ${ }^{3}$ I.U. de Matemàtica Pura i Aplicada, Universitat Politècnica de València, Valencia, 46022, Spain \\ E-mails:1 fergarga@esp.upv.es; ${ }^{2}$ jairoa.gonzalez@upb.edu.co; ${ }^{3}$ fraguima@upvnet.upv.es; ${ }^{4}$ jaolmun@ade.upv.es
}

Received 18 August 2020; accepted 10 October 2020; published 30 December 2020

\begin{abstract}
This paper extends the stochastic mean-semivariance model to a fuzzy multiobjective model, where apart from return and risk, also liquidity is considered to measure the performance of a portfolio. Uncertainty of future return and liquidity of each asset are modeled using L-R type fuzzy numbers that belong to the power reference function family. The decision process of this novel approach takes into account not only the multidimensional nature of the portfolio selection problem but also realistic constraints by investors. Particularly, it optimizes the expected return, the semivariance and the expected liquidity of a given portfolio, considering cardinality constraint and upper and lower bound constraints. The constrained portfolio optimization problem resulting is solved using the algorithm NSGA-II. As a novelty, in order to select the optimal portfolio, this study defines the credibilistic Sortino ratio as the ratio between the credibilistic risk premium and the credibilistic semivariance. An empirical study is included to show the effectiveness and efficiency of the model in practical applications using a data set of assets from the Latin American Integrated Market.
\end{abstract}

Keywords: Fuzzy portfolio selection; L-R Fuzzy numbers; Credibility theory; Mean-Semivariance-Liquidity; Evolutionary multiobjective optimization; Emerging financial markets

Reference to this paper should be made as follows: García, F., González-Bueno, J., Guijarro, F., Oliver, J. 2020. A multiobjective credibilistic portfolio selection model. Empirical study in the Latin American integrated market. Entrepreneurship and Sustainability Issues, 8(2), 1027-1046. http://doi.org/10.9770/jesi.2020.8.2(62)

JEL Classifications: G11, G17

\section{Introduction}

Multi-criteria decision making includes a group of operational research methods that pursue decision making in the presence of multiple criteria, goals, or objectives. This type of method differs from traditional single-objective operational research methods and is intended to support decision makers in the simultaneous optimization of several objectives that usually conflict with each other (Čižo et al., 2020) and those related to financial investments are not an exception (Aznar \& Guijarro, 2016; García et al., 2013, 2018; García, González-Bueno, 


\section{ENTREPRENEURSHIP AND SUSTAINABILITY ISSUES}

ISSN 2345-0282 (online) http://jssidoi.org/jesi/

2020 Volume 8 Number 2 (December)

http://doi.org/10.9770/jesi.2020.8.2(62)

Make your research more visible, join the Twitter account of ENTREPRENEURSHIP AND SUSTAINABILITY ISSUES: @Entrepr69728810

Oliver, \& Riley, 2019; Masood et al., 2019). A characteristic example of multi-criteria decision making is the portfolio selection problem.

Portfolio selection is concerned with the allocation of investor's wealth amongst different types of financial securities. The main goal is to minimize the risk of terminal wealth while the expected terminal wealth equals a prescribed level. The first breakthrough work on this topic was the seminal mean-variance model by Markowitz, (1952). In this classical work, Markowitz used the mathematical expectation of the portfolio's return and its variance as the return and the risk measures, respectively. However, when portfolio returns are typically asymmetric, the variance becomes a less appropriate risk measure, because it considers high returns that investors want as equally undesirable as low returns that investors dislike ( $\mathrm{Li} \&$ Qin, 2014). In other words, both risk measures penalize extreme upside (gains) and downside (losses) deviations from the expected return (Gupta, Mittal, et al., 2013). In order to solve this problem, several downside risk measures (i.e. measures that only consider the negative deviations from a reference return level) have been proposed: semivariance (Markowitz, 1959), lower partial moment (Bawa, 1975; Fishburn, 1977), semi-absolute deviation (Speranza, 1993), value at risk (VaR) (J.P.Morgan, 1996), and conditional value at risk (CVaR) (Rockafellar \& Uryasev, 2000, 2002). Semivariance is one of the most commonly accepted downside risk measures. Its main advantage over variance is that it does not consider values beyond the critical value (i.e. gains) as risk (Gupta, Mittal, et al., 2013). Furthermore, it is a more appropriate risk measure when an investor is concerned about underperformance rather than over performance of the portfolio (Markowitz et al., 1993).

The traditional portfolio optimization model focuses only on the risk-return trade-off (García et al., 2015; Markowitz, 1952; Speranza, 1993). However, it is important to consider other criteria which might generate equal or greater satisfaction level for investors. By considering other criteria in the portfolio selection model, it may be possible to obtain portfolios in which a less favorable return or risk is compensated by portfolio's performance as measured by other criteria (Gupta, Inuiguchi, et al., 2013).

Other than return and risk, liquidity is also one of the main concerns for investors when making decisions. Liquidity has been considered as a fuzzy variable on portfolio decision-making in previous studies (Arenas-Parra et al., 2001; Gupta et al., 2008, 2010, 2011; Jalota et al., 2017a, 2017b). Generally, investors' preference is to own portfolios that contain liquid assets which can be easily liquidated in the future. Therefore, it is reasonable to include liquidity as an additional criterion in the mean-semivariance base model, in order to make this model more realistic and usable in a real situation.

In most of the above-referred studies, asset returns were assumed to be a random variable, and portfolio selection models were developed under the assumption that future asset performance may be correctly captured by past asset performance. However, stock markets are complex and randomness is not the only type of uncertainty actually (Huang, 2010). Moreover, stock markets are affected by vagueness and ambiguity associated to linguistic expressions such as "high risk", "low profit" and "low liquidity" used by investors and investment experts (Gupta, Inuiguchi, et al., 2013; Gupta, Mittal, et al., 2013). Owing to vague and ambiguous information, the fuzzy set theory (Zadeh, 1965) has been used for capturing and modeling the information about investor's subjective preferences in portfolio investment. Assuming that returns are fuzzy, a vast literature is available applying possibility measures on the portfolio selection problem (Carlsson et al., 2002; Vercher et al., 2007; Vercher \& Bermúdez, 2012; Wang \& Zhu, 2002). Although possibility measures are widely used, they are not self-dual (Huang, 2008, 2009, 2010). As an alternative, Liu and Liu (B. Liu \& Liu, 2002) proposed a self-dual credibility measure to overcome the limitations of the possibility measure. Since then, some researchers suggest modeling 


\section{ENTREPRENEURSHIP AND SUSTAINABILITY ISSUES}

ISSN 2345-0282 (online) http://jssidoi.org/jesi/

2020 Volume 8 Number 2 (December)

http://doi.org/10.9770/jesi.2020.8.2(62)

Make your research more visible, join the Twitter account of ENTREPRENEURSHIP AND SUSTAINABILITY ISSUES: @Entrepr69728810

assets return using credibility measures (García, González-Bueno, Oliver, \& Tamošiūnienė, 2019; Huang, 2006a, 2010, 2006b; Jalota et al., 2017a; Mehlawat, 2016; Vercher \& Bermúdez, 2015).

An important aspect to consider in fuzzy portfolio optimization is the shape of the membership functions that will best fit the historical asset performance data. Portfolio selection models based on fitting of L-R fuzzy numbers (González-Bueno, 2019; Jalota et al., 2017a; Saborido et al., 2016; Vercher \& Bermúdez, 2013, 2015) model the uncertainty of the return on a given portfolio directly instead of using the combination of uncertainties of the individual assets. There are only few studies which model the return of each asset by L-R fuzzy numbers (Jalota et al., 2017b; Vercher, 2008; Vercher et al., 2007). In this paper, we extend the literature on multiobjective portfolio selection model by assuming that the return on each asset is an L-R power fuzzy variable.

Another issue is that portfolio decision-making based on fitting of L-R fuzzy numbers is usually developed in a possibilistic environment. In fact, to the best of our knowledge, there are only three studies which treat portfolio return by means of credibility distributions (Jalota et al., 2017a, 2017b; Vercher \& Bermúdez, 2015). Credibility measures are consistent with the law of excluded middle and the law of contradiction (i.e., they have the selfduality property), which is needed both in theory and in practice. In this way, it is fundamental to study their application as the basic measure of the occurrence of a fuzzy event in the portfolio selection problem.

Most portfolio optimization models in the literature have been evaluated in financial markets such as the Madrid Stock Exchange (Spain) (Bermúdez et al., 2012), the National Stock Exchange of Mumbai (India) (Mehlawat, 2016), the Shanghai Stock Exchange (China) (Ren et al., 2017) and the New York Stock Exchange (USA) (J. Liu et al., 2015), among others. To the best of our knowledge there are not empirical studies that have been developed in Latin American capital markets. Thus, this study makes a contribution to the literature by applying a portfolio optimization model in the Latin American Integrated Market (MILA by its Spanish acronym) which integrates the stock exchange markets of Chile, Colombia, Mexico, and Peru.

The concept of optimal portfolio falls under modern portfolio theory (Markowitz, 1952). It assumes that investors act rationally and always try to minimize risk while striving for the highest return possible. One well-known measure to evaluate portfolio performance is the Sortino ratio (Sortino \& Price, 1994). It is a modification of the Sharpe ratio and focuses on returns that are below a certain threshold. The Sortino ratio exhibits more power and less bias than the Sharpe ratio when the distribution of excess returns is skewed. In order to select the optimal portfolio, in this paper we define for the first time the credibilistic Sortino ratio as the ratio between the credibilistic risk premium and the credibilistic semivariance.

In this paper, the stochastic mean-semivariance portfolio selection model is extended to a credibilistic multiobjective model, where apart from return and risk, also liquidity is considered to measure portfolio performance. Return and liquidity are considered as L-R power fuzzy variables. The decision process of this novel approach considers not only the multidimensional nature of the portfolio selection problem but also realistic constraints required by investors. Concretely, it optimizes the expected return, the semivariance and the expected liquidity of a given portfolio, considering budget, bound and cardinality constraints. The introduction of these realistic constraints convert the problem into a constrained multi-objective problem that is NP-hard, and traditional methods of optimization cannot be used to find efficient portfolios. To overcome this problem, the Non-dominated Sorting Genetic Algorithm II (NSGA-II) is applied. An empirical study is presented to show the effectiveness and efficiency of the proposed approach. 
Make your research more visible, join the Twitter account of ENTREPRENEURSHIP AND SUSTAINABILITY ISSUES: @Entrepr69728810

The remainder of the paper is structured as follows: Section 2 introduces some basic definitions and notations regarding L-R fuzzy numbers and the credibility theory. Section 3 describes the multiobjective credibilistic meansemivariance-liquidity (MCMSL) portfolio selection model. Section 4 presents the solution methodology to solve the above model with the NSGA-II algorithm. Section 5 illustrates our proposal with an empirical study using a data set from the MILA Market. Finally, the main conclusions are drawn in Section 6.

\section{L-R Fuzzy numbers and credibility theory}

This section briefly presents some essential definitions regarding L-R fuzzy numbers and the credibility theory for a better understanding of the proposed multiobjective credibilistic mean-semivariance-liquidity portfolio selection model that is introduced in section 3 .

\subsection{L-R Power fuzzy numbers}

Definition 1. Functions L, R (Dubois \& Prade, 1980). The functions $L_{y}, R:[0,1] \rightarrow[0,1]$ are reference functions of a fuzzy number $\widetilde{\mathrm{A}}=\left(\mathrm{x}, \mu_{\tilde{\mathrm{A}}}(\mathrm{x})\right)$, they satisfy the following conditions:

(i) $\mathrm{L}(1)=\mathrm{R}(1)=0, \mathrm{~L}(0)=\mathrm{R}(0)=1$

(ii) $\mathrm{L}(\mathrm{x})$ and $\mathrm{R}(\mathrm{x})$ are strictly decreasing and upper semicontinuous functions.

Definition 2. L-R Fuzzy number (Dubois \& Prade, 1980). A fuzzy number $\widetilde{\mathrm{A}}$ [i.e. $\widetilde{\mathrm{A}}=\left(\mathrm{a}, \mathrm{b}, \mathrm{c}_{z} \mathrm{~d}\right)_{\mathrm{L}_{\mathbb{w}} \mathbb{R}_{p}}$ ] is said to be an L-R fuzzy number if its membership function has the following form:

$$
\mu_{\mathbb{R}}(\mathrm{x})= \begin{cases}\mathrm{L}_{\mathrm{\pi}}\left(\frac{\mathrm{b}-\mathrm{x}}{\mathrm{b}-\mathrm{a}}\right), & \text { If } \mathrm{a} \leq \mathrm{x}<\mathrm{b} \\ 1_{z}, & \text { If } \mathrm{b} \leq \mathrm{x} \leq \mathrm{c} \\ \mathrm{R}_{\mathrm{p}}\left(\frac{\mathrm{x}-\mathrm{c}}{\mathrm{d}-\mathrm{c}}\right), & \text { If } \mathrm{c}<\mathrm{x} \leq \mathrm{d} \\ 0, & \text { Otherwise }\end{cases}
$$

where $(b-a)$ and $(d-c)$ show the left and right spreads of $\widetilde{A}$, respectively; $[b, c]$ is the core of $\widetilde{A}$, i.e., $[\mathrm{b}, \mathrm{c}]=\left\{\mathrm{x} / \mu_{\mathcal{A}}(\mathrm{x})=1\right\} ; \mathrm{L}_{\pi}$ and $\mathrm{R}_{\mathrm{p}}$ are the reference functions that define the left and right shapes of $\tilde{\mathrm{A}}$, respectively. Following Jalota et al. (2017a), this study considers the reference functions of the power family of positive parameters $\pi$ and $\rho$, where $L_{\pi}(k)=1-x^{\pi}$, and $R_{p}(k)=1-x^{\rho}$, respectively. Throughout this paper, L-R power fuzzy numbers will be denoted by $\widetilde{\mathrm{A}}=(\mathrm{a}, \mathrm{b}, \mathrm{c}, \mathrm{d})_{\mathrm{\pi}, \mathrm{p}}$.

\subsection{Credibility theory}

Credibility theory, founded by B. Liu (2004) y refined by B. Liu (2007), is a branch of mathematics that studies the behavior of fuzzy phenomena.

Definition 3. Credibility measure (B. Liu \& Liu, 2002). Let $\xi$ be a fuzzy variable with membership function $\mu$, and $x$ a real number. The credibility measure of a fuzzy event, characterized by $\xi \leq x$, is defined by eq. (1).

$$
\operatorname{Cr}\{\xi \leq \mathrm{x}\}=\frac{1}{2}\left(\sup _{\mathrm{y} \leq \mathrm{x}} \mu(\mathrm{y})+\underset{\mathrm{y} \approx \mathrm{x}}{1-\sup _{\mathrm{N}}} \mu(\mathrm{y})\right), \quad \forall \mathrm{x} \in \mathrm{R}
$$

The credibility measure $\operatorname{Cr}\{\xi \leq x\}$ of L-R power fuzzy numbers is obtained deriving the eq. (1) (Jalota et al., 2017a): 
Make your research more visible, join the Twitter account of ENTREPRENEURSHIP AND SUSTAINABILITY ISSUES: @Entrepr69728810

As $\operatorname{Cr}\{\xi>x\}=1-\operatorname{Cr}\{\xi \leq x\}$, therefore

$$
\operatorname{Cr}\{\xi \leq \mathrm{x}\}= \begin{cases}\frac{0,}{2}\left(1-\left(\frac{\mathrm{b}-\mathrm{x}}{\mathrm{b}-\mathrm{a}}\right)^{\pi}\right), & \text { If } \mathrm{x} \leq \mathrm{a} \\ \frac{1}{2}, \mathrm{x}<\mathrm{b} \\ \frac{1}{2}\left(1+\left(\frac{\mathrm{x}-\mathrm{c}}{\mathrm{d}-\mathrm{c}}\right)^{p}\right), & \text { If } \mathrm{b} \leq \mathrm{x} \leq \mathrm{c}<\mathrm{d} \\ 1_{z} & \text { If } \mathrm{d} \leq \mathrm{x}\end{cases}
$$

$$
\operatorname{Cr}\{\xi>x\}= \begin{cases}\frac{1,}{2}\left(1+\left(\frac{b-x}{b-a}\right)^{\pi}\right), & \text { If } \mathrm{a}<\mathrm{x}<\mathrm{b} \\ \frac{1}{2}, & \text { If } \mathrm{b} \leq \mathrm{x} \leq \mathrm{c} \\ \frac{1}{2}\left(1-\left(\frac{\mathrm{x}-\mathrm{c}}{\mathrm{d}-\mathrm{c}}\right)^{p}\right), & \text { If } \mathrm{c}<\mathrm{x}<\mathrm{d} \\ 0, & \text { If } \mathrm{d} \leq \mathrm{x}\end{cases}
$$

Definition 4. Expected value (B. Liu \& Liu, 2002). Let $\xi$ be a fuzzy variable. Then the expected value of $\xi$ is defined by eq. (2) provided that at least one of the two integrals is finite.

$$
E(\xi)=\int_{0}^{+\infty} \operatorname{Cr}\{\xi \geq x\} d x-\int_{-\infty}^{0} \operatorname{Cr}\{\xi \leq x\} d x
$$

The crisp equivalent expression for the credibilistic expected value of an L-R power fuzzy number is obtained deriving eq. (2) (Jalota et al., 2017a):

$$
E(\xi)=\frac{1}{2}\left[b+c+\frac{\rho(d-c)}{\rho+1}-\frac{\pi(b-a)}{\pi+1}\right]
$$

Definition 5. Semivariance (B. Liu \& Liu, 2002). Let $\xi$ be a fuzzy variable with finite expected value e $=E[\xi]$. Then the semivariance of $\xi$ is defined by eq. (4).

$$
\mathrm{SV}[\xi]=\mathrm{E}\left[\left([\xi-\mathrm{e}]^{-}\right)^{2}\right]
$$

where,

$$
[\xi-e]^{-}= \begin{cases}\xi-\mathrm{e}, & \text { Si } \xi \leq e \\ 0, & \text { Si } \xi>e\end{cases}
$$

Finally, the crisp equivalent expression for the credibility-measure-based semivariance of an L-R power fuzzy number was derived by Jalota et al. (2017a): 
Make your research more visible, join the Twitter account of ENTREPRENEURSHIP AND SUSTAINABILITY ISSUES: @Entrepr69728810

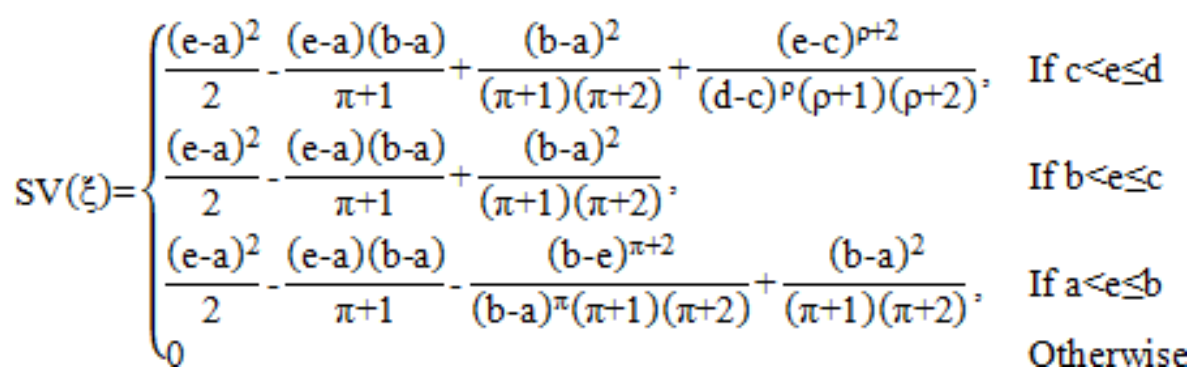

\section{Multiobjective credibilistic mean-semivariance-liquidity portfolio selection model}

In this section, the proposed mathematical model to solve the multiobjective portfolio selection problem in the light of the credibility theory is discussed. The parameters and variables used in this study to formulate this model are:

\section{Parameters}

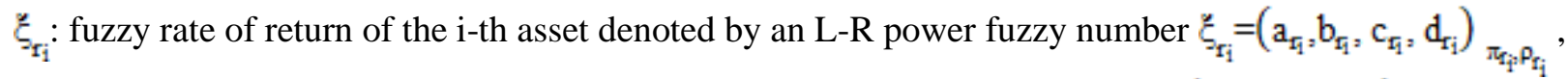

$\xi_{\mathrm{l}_{\mathrm{i}}}$ : fuzzy liquidity of the $\mathrm{i}$-th asset denoted by an L-R power fuzzy number $\xi_{\mathrm{l}_{\mathrm{i}}}=\left(\mathrm{a}_{\mathrm{l}_{\mathrm{i}}}, \mathrm{b}_{\mathrm{l}_{\mathrm{i}},}, \mathrm{C}_{\mathrm{l}_{\mathrm{y}}}, \mathrm{d}_{\mathrm{l}_{\mathrm{i}}}\right)_{\pi_{\mathrm{l}_{\mathrm{i}}}, \mathrm{P}_{\mathrm{i}}}$,

$\xi_{x_{p}}$ : fuzzy expected return of the portfolio denoted by an L-R power fuzzy number $\xi_{x_{p}}=\left(a_{x_{p}}, b_{x_{p}}, c_{x_{p}}, d_{x_{p}}\right){ }_{\pi_{x_{p}}, p_{x_{p}}}$,

e: expected return of the portfolio,

$\mathrm{u}_{\mathrm{i}}$ : maximal fraction of the capital allocated to the $\mathrm{i}$-th asset,

$1_{\mathrm{i}}$ : minimal fraction of the capital allocated to the $\mathrm{i}$-th asset ,

$\mathrm{k}$ : number of assets in the portfolio.

\section{Decision variables}

$\omega_{\bar{i}}$ : proportion of the total funds invested in the $\mathrm{i}$-th asset,

$\mathrm{y}_{\mathrm{i}}$ : a binary variable indicating whether the $\mathrm{i}$-th asset is contained in the portfolio. It takes value 1, if the i-th asset is included in the portfolio, otherwise takes value 0 .

\subsection{Objective functions \\ Return}

Considering that in financial markets several non-probabilistic factors may affect asset returns, this paper assumes that an investor has decided to allocate his/her total wealth among n risky assets that offer fuzzy returns. The core, support and shape parameters of the fuzzy return of each asset are obtained from the empirical percentiles of their historical returns (Vercher, 2008; Vercher \& Bermúdez, 2012, 2013, 2015). The support of $\xi_{\mathrm{Fi}_{\mathrm{i}}}$, that is, the interval $\left[\mathrm{a}_{\mathrm{r}_{\mathrm{i}},}, \mathrm{d}_{\mathrm{ri}_{\mathrm{i}}}\right]$ is given by the 3th and 97th percentile, respectively. The core of $\xi_{\mathrm{Ir}_{\mathrm{i}}}$, that is, the interval $\left[\mathrm{b}_{\mathrm{ri}_{\mathrm{i}},} \mathrm{c}_{\mathrm{ri}_{\mathrm{i}}}\right]$ is given by the 45 th and 55 th percentile, respectively. The positive shape parameters $\pi_{r_{\mathrm{i}}}$ and $\rho_{\mathrm{I}_{\mathrm{j}}}$ are obtained in such a way that the fuzzy and empirical quartiles coincide, that is, $\pi_{\mathrm{r}_{\mathrm{i}}}=\frac{\operatorname{Ln} 0.5}{\ln \mathrm{s}}$, where $\mathrm{s}=\frac{\mathrm{b}_{\mathrm{r}_{\mathrm{i}}}-25 \text { th percentile }}{b_{\mathrm{r}_{\mathrm{i}}} \mathrm{a}_{\mathrm{I}_{\mathrm{i}}}}$, and $\rho_{\mathrm{r}_{\mathrm{i}}}=\frac{\operatorname{In} 0.5}{\operatorname{lnh}}$, where $h=\frac{75 \text { th percentile }-c_{x_{i}}}{d_{x_{f}} c_{x_{i}}}$. Then, the maximization of the expected return of the portfolio can be expressed as: 
Make your research more visible, join the Twitter account of ENTREPRENEURSHIP AND SUSTAINABILITY ISSUES: @Entrepr69728810

$$
\operatorname{Max} F_{1}\left(\omega_{i}\right)=\sum_{i=1}^{n}\left[\left[\frac{1}{2}\left[b_{r_{1}}+c_{r_{1}}+\frac{\left(d_{r_{1}}-c_{r_{1}}\right) \rho_{r_{1}}}{\rho_{r_{1}}+1}-\frac{\left(b_{r_{1}}-a_{r_{1}}\right) \pi_{r_{1}}}{\pi_{r_{1}}+1}\right]\right] \omega_{i}\right]
$$

\section{Risk}

Portfolio risk is estimated by means of the semivariance measure. Thus, the minimization of semi-variance of the portfolio can be expressed as:

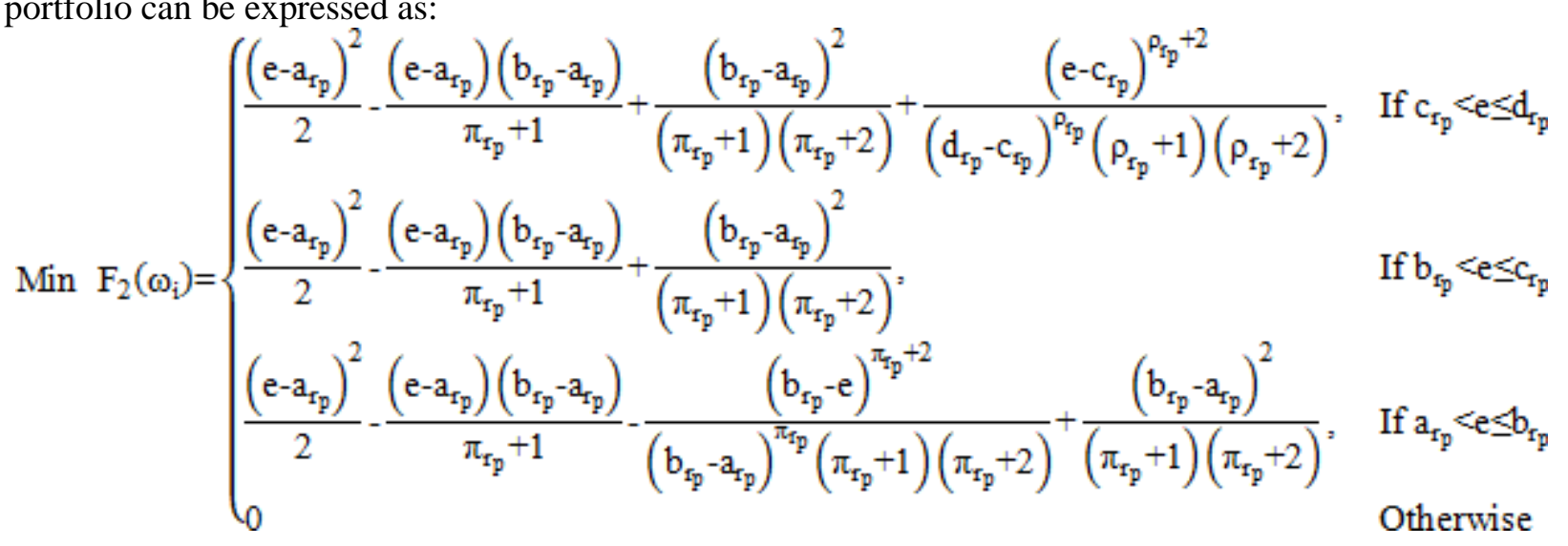

\section{Liquidity}

Liquidity is one of the most important aspects that concern decision-makers in portfolio selection. Liquidity is defined as the probability of converting an investment into cash without any significant loss in value (ArenasParra et al., 2001; Gupta, Mittal, et al., 2013). Generally, investors prefer portfolios which can be liquidated at higher expected values as well as portfolios for which liquidation values are more certain. In this study, the liquidity of an asset is defined by the stock liquidity indicator:

$$
\text { Liquidity }=\frac{\mathrm{DOT}}{\mathrm{TDP}}\left(\sqrt{\left(\frac{\mathrm{NST}}{\mathrm{TAS}}\right)\left(\frac{\mathrm{TSV}}{\mathrm{TAV}}\right)}\right)
$$

where DOT is the number of days within the observed period in which the stock was at least traded once; TDP is the total number of days in the period; NST is the number of stock trades during the period; TAS is the total trades of all stocks during the period; TSV is the trading stock volume in USD in the period and TAV is the trading volume of all stocks in USD in the period.

Because of incomplete information, stock liquidity indicators are only vague estimates. This study assumes that the indicators of stock liquidity are fuzzy numbers. The parameters of the L-R power fuzzy numbers are obtained from the empirical percentiles of the historical liquidity data, as previously explained. The maximization of the expected liquidity of the portfolio can be expressed as:

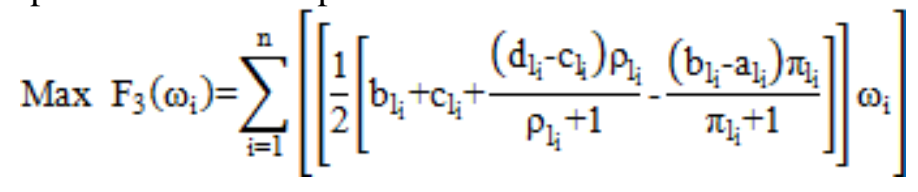


Make your research more visible, join the Twitter account of ENTREPRENEURSHIP AND SUSTAINABILITY ISSUES: @Entrepr69728810

\subsection{Constraints}

Capital budget constraint on the assets is expressed as

No short selling of assets is expressed as

$$
\sum_{i=1}^{n} \omega_{i}=1
$$

$$
\omega_{i} \geq 0, \quad \mathrm{i}=1,2, \ldots, \mathrm{n}
$$

Maximal fraction of the capital that can be invested in a single asset is expressed as

$$
\omega_{\mathrm{i}} \leq \mathrm{u}_{\mathrm{i}} \mathrm{y}_{\mathrm{i}}, \quad \mathrm{i}=1,2, \ldots, \mathrm{n}
$$

Minimal fraction of the capital that can be invested in a single asset is expressed as

$$
\omega_{\mathrm{i}} \geq \mathrm{l}_{\mathrm{i}} \mathrm{y}_{\mathrm{i}}, \quad \mathrm{i}=1,2, \ldots, \mathrm{n}
$$

Number of assets held in the portfolio is expressed as

$$
\sum_{\mathrm{i}=1}^{\mathrm{n}} \mathrm{y}_{\mathrm{i}}=\{0,1\}, \quad \mathrm{i}=1,2, \ldots, \mathrm{n}
$$

\subsection{The decision problem}

The multiobjective credibilistic mean-semivariance-liquidity portfolio selection model is formulated as:

$$
\begin{aligned}
& \operatorname{Max} F_{1}\left(\omega_{i}\right) \\
& \operatorname{Min} F_{2}\left(\omega_{i}\right) \\
& \operatorname{Max} \mathrm{F}_{3}\left(\omega_{\mathrm{i}}\right) \\
& \text { s.t. } \begin{cases}\sum_{\mathrm{i}=1}^{\mathrm{n}} \omega_{\mathrm{i}}=1, & \mathrm{i}=1,2, \ldots, \mathrm{n} \\
\omega_{\mathrm{i}} \geq 0, & \mathrm{i}=1,2, \ldots, \mathrm{n} \\
\omega_{\mathrm{i}} \leq \mathrm{u}_{\mathrm{i}} \mathrm{y}_{\mathrm{i}}, & \mathrm{i}=1,2, \ldots, \mathrm{n} \\
\omega_{\mathrm{i}} \geq 1_{\mathrm{i}} \mathrm{y}_{\mathrm{i}}, & \mathrm{i}=1,2, \ldots, \mathrm{n} \\
\sum_{\mathrm{i}=1}^{\mathrm{n}} \mathrm{y}_{\mathrm{i}}=\mathrm{k} & \\
\mathrm{y}_{\mathrm{i}} \in\{0,1\}, & \mathrm{i}=1,2, \ldots, \mathrm{n}\end{cases}
\end{aligned}
$$

Following Vercher and Bermúdez (2013), an admissible portfolio $\mathrm{P}^{\mathrm{a}}$ is said to be Pareto-efficient if there is no

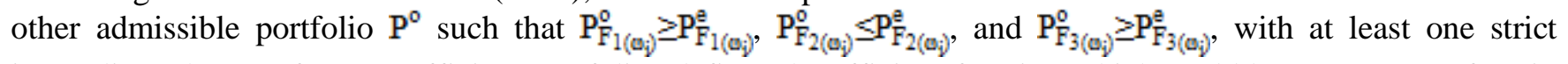
inequality. The set of Pareto-efficient portfolios defines the efficient frontier, which could be seen as a surface in the 3-D space of the three objectives F (F1, F2, F3). 
ENTREPRENEURSHIP AND SUSTAINABILITY ISSUES

ISSN 2345-0282 (online) http://jssidoi.org/jesi/

2020 Volume 8 Number 2 (December)

http://doi.org/10.9770/jesi.2020.8.2(62)

Make your research more visible, join the Twitter account of ENTREPRENEURSHIP AND SUSTAINABILITY ISSUES: @Entrepr69728810

\section{Solution methodology}

In the above paragraph, a multiobjective credibilistic portfolio selection model was formulated where their objective functions correspond to the crisp goals of return, risk and liquidity. Note that the calculation of expected return, downside risk and expected liquidity depends on both i) the characteristics of the L-R power fuzzy returns and the L-R power fuzzy liquidity of each asset, and ii) the average of the fuzzy numbers. Furthermore, the introduction of realistic constraints into the suggested model convert the problem from a classical quadratic optimization problem to a quadratic mixed-integer problem that is NP-hard. In order to overcome this drawback, multiobjective evolutionary algorithms (MOEAs) have been successfully applied for generating solutions of the constrained portfolio optimization problems.

The most commonly-used MOEA for solving the constrained portfolio optimization problem is the Nondominated Sorting Genetic Algorithm II (NSGA-II) (Liagkouras \& Metaxiotis, 2015), first introduced by Deb et al. (2002), which is the one applied in our study. The procedural steps of this algorithm are those described by Deb et al. (2002) and Palanikumar et al. (2009).

The experimental parameters' configuration for testing this algorithm are: population size (400), distribution index for crossover (10); probability of crossover (0.9); distribution index for mutation (50); probability of mutation (0.01); and the maximum number of generations (500). Fig. 1 shows the overall structure of the MCMSL modelling approach.

\section{Experimental results}

\subsection{Data description}

The Latin American Integrated Market is an integrated trading venture between the stock markets of Chile, Colombia, Mexico and Peru that began operating in May 30, 2011. MILA market allows, for example, Mexican investors to buy Chilean or Colombian securities without the need to open brokerage accounts in these two foreign stock markets. While the individual MILA markets are relatively small, their combination provides investors with a larger set of securities to choose. In this way, they can extend their possibilities of diversification and potentially improve the risk-return trade-off in their portfolios.

In order to illustrate the usefulness of the MCMSL model, this paper presents a real-world empirical study using for the first time a data set extracted from the MILA market. The data correspond to weekly closing adjusted prices and their indicators of stock liquidity, observed in $t=239$ periods from June 03, 2011 until December 25, 2015. According to the World Federation of Exchanges (WFE) by the end of 2015 the number of listed companies in the MILA market were 804. The candidate stocks to be included in the investment portfolio must meet following two conditions during the study period: i) they have been traded every week; and ii) they have an average monthly trading volume higher than the average monthly trading volume presented on their own national stock market. Once these conditions are considered, only 29 assets, $n=29$ are available. The exchange codes of the 29 assets are PFDAVVNDA, PFBCOLOM, CORFICOLCF, ALFA, ALSEA, AC, ASUR, BIMBO, BOLSA, CEMEX, KOF, FEMSA, GCARSO, GENTERA, GFNORTE, GMEXICO, GAP, MASECA, KIMBER, LIVERPOOL, TLEVISA, AESGENER, AGUAS-A, CHILE, BCI, ITAUCORP, CCU, ENELCHILE and SM- 
Make your research more visible, join the Twitter account of ENTREPRENEURSHIP AND SUSTAINABILITY ISSUES: @Entrepr69728810

CHILE B. For convenience in the description of the notation, we label these 29 assets successively as A1, A2,.., A29.

\subsection{Results}

Returns of assets rit are obtained as $\mathrm{r}_{\mathrm{it}}=\left(\mathrm{p}_{\mathrm{it}}-\mathrm{p}_{\mathrm{it}-1}\right) /\left(\mathrm{p}_{\mathrm{it}-1}\right), \mathrm{i}=1,2, \ldots, 29 ; \mathrm{t}=1,2, \ldots, 239$, where pit is the closing price of the $\mathrm{i}$-th asset on Friday of week t. Then, the membership function of the L-R fuzzy return $\left(\xi_{\mathrm{r}_{1}}\right)$ and the liquidity $\left(\xi_{\mathrm{I}_{1}}\right)$ are obtained from the empirical percentiles of their historical returns and indicators of stock liquidity, respectively, as was explained in Section 3.

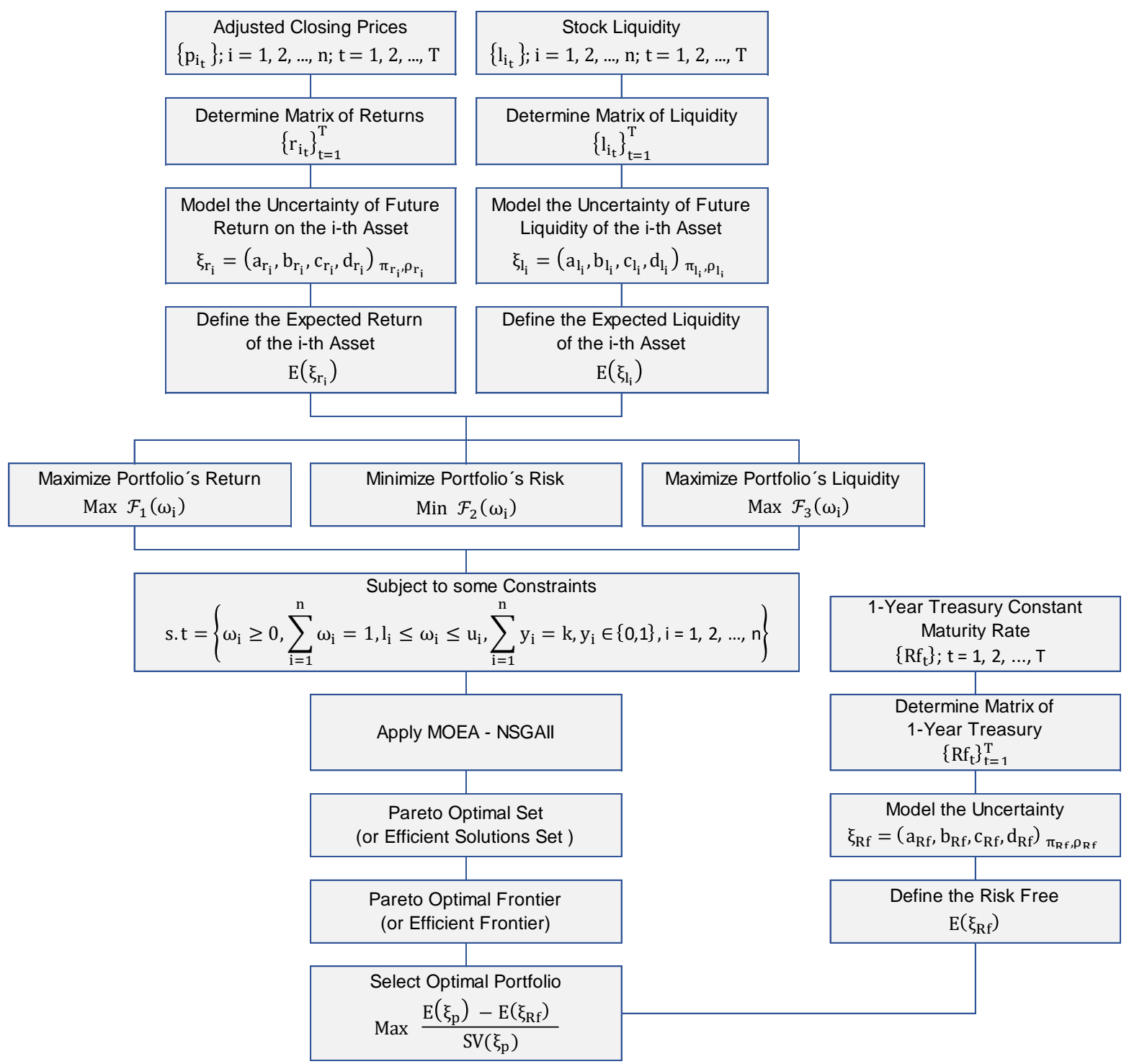

Figure 1. Overall structure of the MCMSL modelling approach. 


\section{ENTREPRENEURSHIP AND SUSTAINABILITY ISSUES}

ISSN 2345-0282 (online) http://jssidoi.org/jesi/ 2020 Volume 8 Number 2 (December) http://doi.org/10.9770/jesi.2020.8.2(62)

Make your research more visible, join the Twitter account of ENTREPRENEURSHIP AND SUSTAINABILITY ISSUES: @Entrepr69728810

Tables 1 and 2 show the fuzzy data regarding return and liquidity for the 29 selected assets, and their crisp credibilistic mean values. When the parameters of the membership function of each L-R fuzzy return are analyzed, it is noted that the left and right spreads are different, i.e., $(b-a) \neq(d-c)$. This evidence confirms the existence of asymmetry in the 29 fuzzy returns and, therefore, the choice of the semivariance was the most appropriate decision.

Table 1. L-R Fuzzy return of the assets and their crisp credibilistic mean values.

\begin{tabular}{|c|c|c|}
\hline \multirow[b]{2}{*}{ Asset } & Return & \multirow{2}{*}{$\begin{array}{c}\text { Crisp } \\
\text { Credibilistic } \\
\text { Mean Values }\end{array}$} \\
\hline & 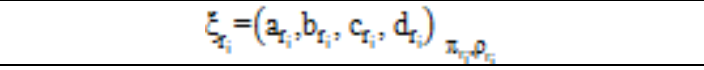 & \\
\hline A1 & $(-0.06563,-0.00409,0.00547,0.06565) L_{0.5224} \mathbb{R}_{0.4}$ & -0.000597 \\
\hline A2 & $\left(-0.08206_{3}-0.00327,0.00455_{z}, 0.06183\right) \mathrm{L}_{0.44442} \mathrm{R}_{0.48993}$ & -0.002076 \\
\hline A3 & $\left(-0.05837_{z}-0.00013,0.00472,0.05250\right) L_{0.56591} R_{0.04}$ & -0.000703 \\
\hline A4 & $\left(-0.07862_{2}-0.00397,0.00434_{z} 0.09799\right) L_{0.62926} R_{0.46993}$ & 0.000740 \\
\hline A5 & $(-0.07891,0.00167,0.01302,0.09301) L_{0.48751} R_{0.5}$ & 0.007611 \\
\hline A6 & $(-0.06550,-0.00409,0.00241,0.07315) L_{0.49951} R_{0.57142}$ & 0.001791 \\
\hline A7 & $(-0.06155,0.00249,0.00907,0.07653) \mathrm{L}_{0.66725} \mathrm{R}_{0.51298}$ & 0.004403 \\
\hline A8 & $\left(-0.07114_{z}-0.00197,0.00579,0.08474\right) L_{0.54195} R_{0.52523}$ & 0.00 \\
\hline A9 & $(-0.08642,-0.00355,0.00646,0.08604) L_{053855} \mathrm{R}_{0.43870}$ & -0.000917 \\
\hline $\mathrm{A} 10$ & $\left(-0.11207,-0.00194_{z} 0.00629,0.10866\right) L_{0.52320} R_{0.52155}$ & 0.000806 \\
\hline A11 & $\left(-0.07077_{z}-0.00355_{z}, 0.00648,0.06321\right) L_{0.4756} \mathrm{R}_{0.65197}$ & 0.001613 \\
\hline $\mathrm{A} 12$ & $(-0.06426,0.00018,0.00717,0.06823) \mathrm{L}_{0.65239} \mathrm{R}_{0.50229}$ & 0.001401 \\
\hline A13 & $(-0.08142,-0.00105,0.00605,0.08889) L_{0.50132} R_{0.49297}$ & 0.002760 \\
\hline A14 & $(-0.09610,-0.00336,0.00596,0.08619) L_{0.4596} R_{0.63966}$ & 0.0 \\
\hline $\mathrm{A} 15$ & $\left(-0.08624_{z}-0.00779,0.00423,0.09266\right) L_{0.46855} R_{0.58855}$ & 0.002094 \\
\hline $\mathrm{A} 16$ & $\left(-0.08441_{z}-0.00368,0.00737,0.08382\right) L_{0.64722} R_{0.49659}$ & -0.001333 \\
\hline A17 & $(-0.05605,-0.00181,0.00663,0.08016) L_{0.61356} R_{0.5}$ & 0.004919 \\
\hline $\mathrm{A} 18$ & $(-0.06769,0.00158,0.01217,0.08745) L_{0.53070} R_{0.57264}$ & 0.008572 \\
\hline A19 & $\left(-0.07189_{z}-0.00102,0.00697,0.07995\right) L_{0.65163} R_{0.55270}$ & 0.001981 \\
\hline $\mathrm{A} 20$ & $(-0.05932,-0.00004,0.00711,0.07472) L_{0,59170} R_{0.43667}$ & 0.002775 \\
\hline $\mathrm{A} 21$ & $\left(-0.07145_{z}-0.00108_{z}, 0.00768_{z}, 0.06401\right) L_{052438} R_{0.57310}$ & 0.001456 \\
\hline $\mathrm{A} 22$ & $(-0.05726,-0.00447,0.00306,0.06548) L_{0.55931} R_{0.54310}$ & 0.000812 \\
\hline $\mathrm{A} 23$ & $\left(-0.04633_{s}-0.00194,0.00276,0.05853\right) L_{0.53680} R_{0.49413}$ & 0.001879 \\
\hline A24 & $(-0.04980,-0.00233,0.00206,0.04733) L_{05095}-R_{0.57071}$ & 0.000077 \\
\hline $\mathrm{A} 25$ & $\left(-0.06457_{z}-0.00668,0.00129,0.08281\right) L_{059895} R_{0.49487}$ & -0.000042 \\
\hline $\mathrm{A} 26$ & $\left(-0.07181_{z}-0.00689_{z} 0.00091_{z}, 0.08026\right) L_{0.44877} R_{0.46717}$ & -0.000413 \\
\hline A27 & $\left(-0.06371_{z}-0.00334_{z}, 0.00265,0.07772\right) L_{0.59105} R_{0.46957}$ & 0.000436 \\
\hline $\mathrm{A} 28$ & $(-0.06730,-0.00372,0.00396,0.06537) L_{0.49137} R_{0.47871}$ & -0.000411 \\
\hline $\mathrm{A} 29$ & $(-0.05243,-0.00304,0.00226,0.05724) L_{0.56215} R_{0.48733}$ & -0.000270 \\
\hline
\end{tabular}




\section{ENTREPRENEURSHIP AND SUSTAINABILITY ISSUES}

ISSN 2345-0282 (online) http://jssidoi.org/jesi/ 2020 Volume 8 Number 2 (December)

http://doi.org/10.9770/jesi.2020.8.2(62)

Make your research more visible, join the Twitter account of ENTREPRENEURSHIP AND SUSTAINABILITY ISSUES: @Entrepr69728810

Table 2. L-R Fuzzy liquidity of the assets and their crisp credibilistic mean values.

\begin{tabular}{|c|c|c|}
\hline \multirow{2}{*}{ Asset } & Liquidity & \multirow{2}{*}{$\begin{array}{c}\text { Crisp } \\
\text { Credibilistic } \\
\text { Mean Values } \\
\end{array}$} \\
\hline & 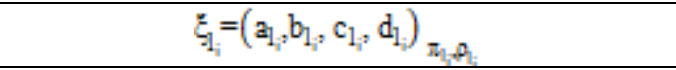 & \\
\hline A1 & $(0.01291,0.02715,0.02912,0.06874) L_{0.62085} R_{0.36660}$ & 0.030722 \\
\hline A2 & $(0.04013,0.08476,0.09240,0.19457) L_{0.91198} R_{0.41446}$ & 0.092907 \\
\hline $\mathrm{A} 3$ & $(0.00751,0.01740,0.01861,0.03363) L_{0.77838} R_{0.54519}$ & 0.018482 \\
\hline A4 & $(0.01364,0.03709,0.04012,0.06481) L_{0.7859}, R_{0.48410}$ & 0.037472 \\
\hline A5 & $(0.00168,0.01045,0.01238,0.02947) L_{1.35871} R_{0.48594}$ & 0.011686 \\
\hline A6 & $(0.00710,0.01581,0.01708,0.02538) L_{0.73018} R_{0.75133}$ & 0.016395 \\
\hline $\mathrm{A} 7$ & $(0.00323,0.01000,0.01119,0.02628) L_{0.87060} \mathbb{R}_{0.46760}$ & 0.011421 \\
\hline A8 & $(0.00944,0.01572,0.01665,0.02559) L_{0.711]} \mathbb{R}_{0.47475}$ & 0.016319 \\
\hline A9 & $(0.00465,0.00879,0.00976,0.01652) L_{0.8490} R_{0.52747}$ & 0.009491 \\
\hline $\mathrm{A} 10$ & $(0.03596,0.05853,0.06173,0.09610) L_{0.88499} R_{0.49827}$ & 0.060546 \\
\hline A11 & $(0.00363,0.01463,0.01568,0.02662) L_{0.6252} R_{0.40619}$ & 0.014618 \\
\hline $\mathrm{A} 12$ & $(0.02007,0.03671,0.03954,0.05317) L_{0.56785} R_{0.50087}$ & 0.037388 \\
\hline A13 & $\left(0.00224_{z}, 0.00619,0.00671,0.01224\right) L_{0.64051} R_{0.48743}$ & 0.006586 \\
\hline $\mathrm{A} 14$ & $(0.00652,0.01603,0.01780,0.02964) \mathrm{L}_{0.65278} \mathrm{R}_{0.57994}$ & 0.017247 \\
\hline A15 & $(0.02632,0.05827,0.06189,0.09972) L_{0.75832} R_{0.52887}$ & 0.059734 \\
\hline A16 & $(0.03861,0.05606,0.05886,0.08984) \mathrm{L}_{0.59576} \mathrm{R}_{0.45777}$ & 0.059066 \\
\hline A17 & $(0.00445,0.01091,0.01264,0.02696) L_{0.6936} \mathrm{R}_{0.51466}$ & 0.012885 \\
\hline A18 & $(0.00340,0.01333,0.01706,0.03893) L_{1.59962} R_{0.69049}$ & 0.016613 \\
\hline A19 & $(0.00824,0.02193,0.02388,0.03615) L_{1.20490} R_{0.65311}$ & 0.021585 \\
\hline $\mathrm{A} 20$ & $(0.00300,0.00812,0.00882,0.01954) \mathrm{L}_{1.01010} \mathrm{R}_{0.37608}$ & 0.008648 \\
\hline $\mathrm{A} 21$ & $(0.02128,0.03348,0.03586,0.05167) L_{0.65427} R_{0.60188}$ & 0.035228 \\
\hline A22 & $(0.00966,0.01667,0.01828,0.03466) L_{0.7939} R_{0.41382}$ & 0.018320 \\
\hline $\mathrm{A} 23$ & $(0.01073,0.02375,0.02689,0.04934) \mathrm{L}_{0.7299} \mathrm{R}_{0.54948}$ & 0.026568 \\
\hline $\mathrm{A} 24$ & $(0.02168,0.03806,0.04311,0.09364) L_{0.8524} \mathbb{R}_{0.42108}$ & 0.044302 \\
\hline $\mathrm{A} 25$ & $(0.00920,0.01720,0.01900,0.03361) L_{0.71877} R_{0.52764}$ & 0.018951 \\
\hline $\mathrm{A} 26$ & $(0.00914,0.02256,0.02687,0.06516) L_{0.9144} R_{0.5365}$ & 0.028187 \\
\hline $\mathrm{A} 27$ & $(0.00875,0.01817,0.02043,0.04436) \mathrm{L}_{0.53978} \mathrm{R}_{0.40792}$ & 0.021116 \\
\hline $\mathrm{A} 28$ & $(0.02641,0.05480,0.06132,0.10541) \mathrm{L}_{0.66402} \mathrm{R}_{0.51610}$ & 0.059899 \\
\hline A29 & $(0.00408,0.00770,0.00881,0.02005) L_{0.96212} R_{0.44606}$ & 0.009100 \\
\hline
\end{tabular}

Let us assume that the diversification parameters are given by $\mathrm{li}=0$ and $u i=0.3$ for every $\mathrm{i}=1,2, \ldots, 29$. Following Gupta et al. (2014), it is not advisable to have very few or very large number of assets in the portfolio so as to achieve diversification. According to these authors, portfolio diversification by investors lies in the narrow range of 3-10 assets. Thus, following this recommendation, this study considers to set $\mathrm{k}=10$ assets for an admissible portfolio. 


\section{ENTREPRENEURSHIP AND SUSTAINABILITY ISSUES}

ISSN 2345-0282 (online) http://jssidoi.org/jesi/

2020 Volume 8 Number 2 (December)

http://doi.org/10.9770/jesi.2020.8.2(62)

Make your research more visible, join the Twitter account of ENTREPRENEURSHIP AND SUSTAINABILITY ISSUES: @Entrepr69728810

Fig. 2 shows a 3-dimensional plot of the final populations generated by NSGA-II for the MCMSL model. The group of points represents the set of non-dominated solutions (or efficient portfolios) for which none of the three objectives (return-risk-liquidity) can be improved without deteriorating another objective. NSGA-II supplies sets of efficient portfolios distributed over the Pareto optimal front, which provide investors with a true picture of trade-offs. Furthermore, each pair of functions has been plotted in bi-dimensional images in Fig. 3. It can be observed that bi-objective coverages of these Pareto optimal fronts present a suitable performance.

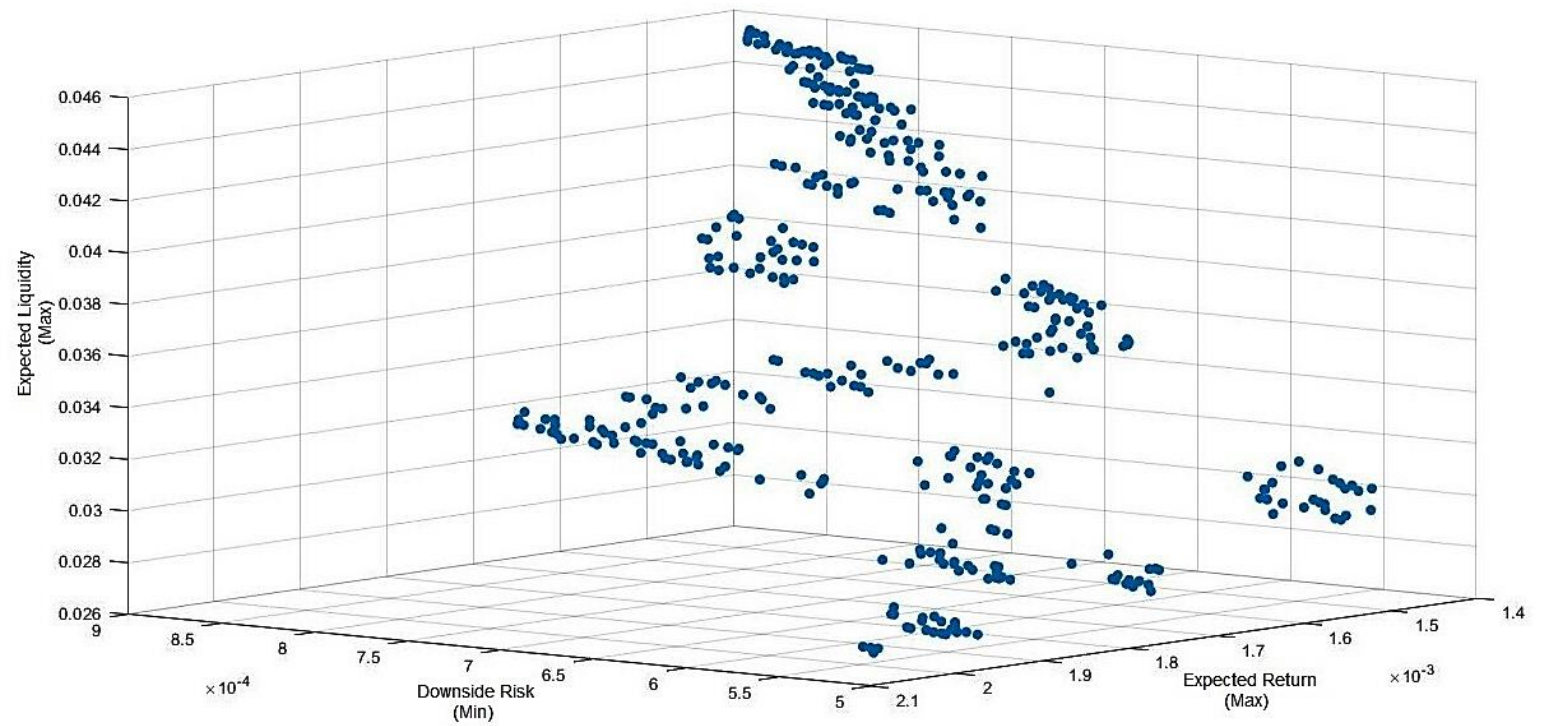

Figure 2. Pareto optimal front of the MCMSL model

Additionally, it is worthy to analyze the influence of the inclusion of liquidity as an additional portfolio selection criterion. Figure 3a shows that portfolios with the highest liquidity have the highest risk and the lowest return. Furthermore, high-return portfolios have medium and low risk but are rather illiquid. This outcome is confirmed by Fig. $3 \mathrm{~b}$ and 3c. As expected, it is not possible for any portfolio to score well in all three criteria. There is no portfolio that dominates the rest in terms of achieving high return, low risk and at the same time being very liquid. For that reason, the most liquid portfolios are riskier and less profitable than their peers, while the most illiquid portfolios, in turn, are less risky and more profitable.

In order to analyze the relationship between the three criteria (return, risk and liquidity), Spearman's rank partial correlation coefficient is applied. Doing this, the coherence of the relationship between return and risk can be checked, removing the influence of liquidity on both variables. We expect both variables to have a positive correlation, but the previous graphical analysis of Fig. 3a-c does not provide a clear answer. Furthermore, thanks to Spearman's rank partial correlation coefficient we can get to know the relationship of both variables with liquidity. As presented in Table 3, there is a positive correlation between return and risk, meaning that more profitable portfolios are riskier. Regarding liquidity, more liquid portfolios are risker, but less profitable. Conversely, less liquid portfolios are less risky and more profitable. 


\section{ENTREPRENEURSHIP AND SUSTAINABILITY ISSUES}

ISSN 2345-0282 (online) http://jssidoi.org/jesi/

2020 Volume 8 Number 2 (December)

http://doi.org/10.9770/jesi.2020.8.2(62)

Make your research more visible, join the Twitter account of ENTREPRENEURSHIP AND SUSTAINABILITY ISSUES: @Entrepr69728810

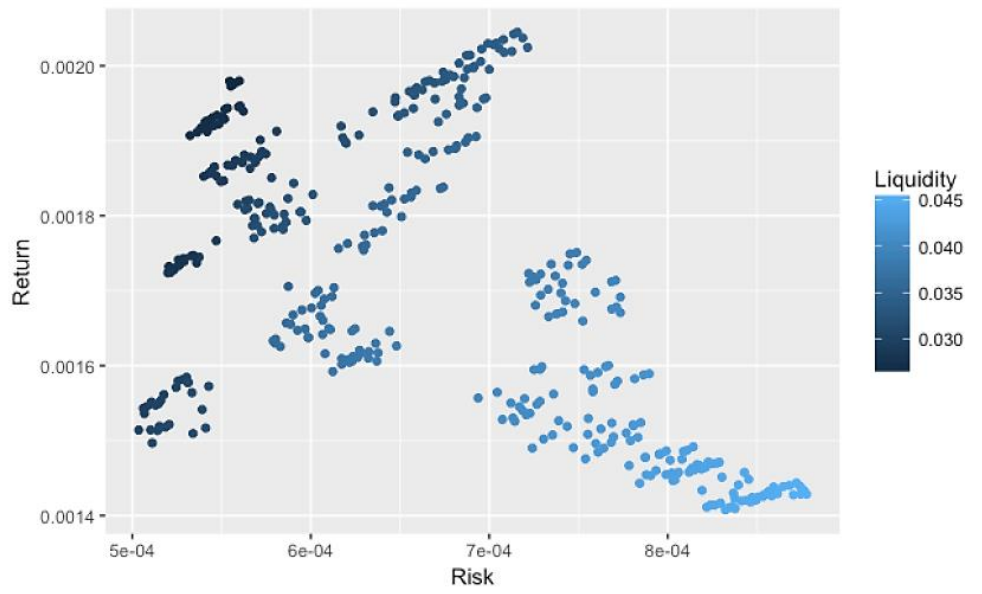

(a) Downside Risk vs. Expected Return

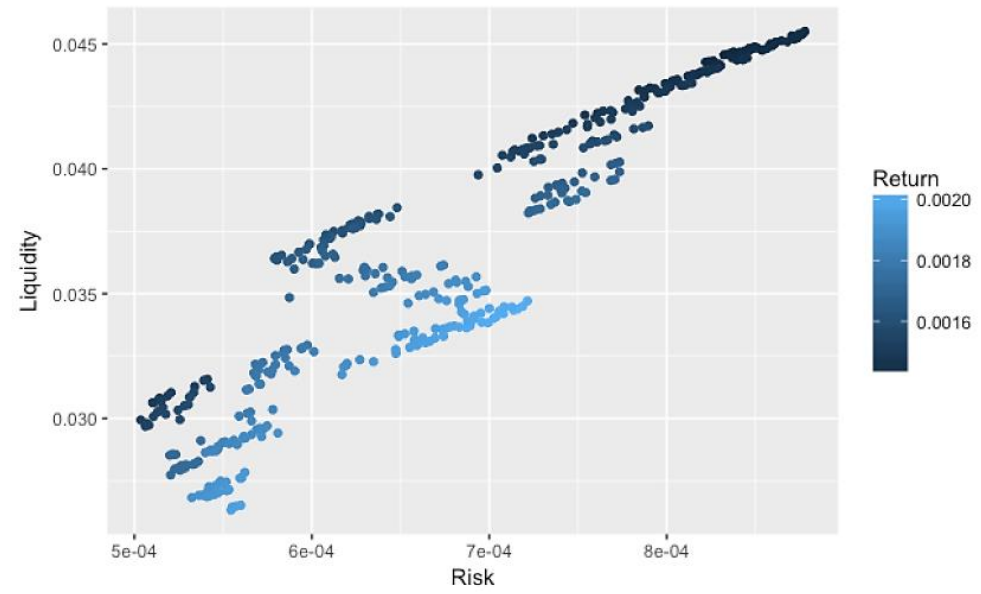

(b) Expected Liquidity vs. Expected Return

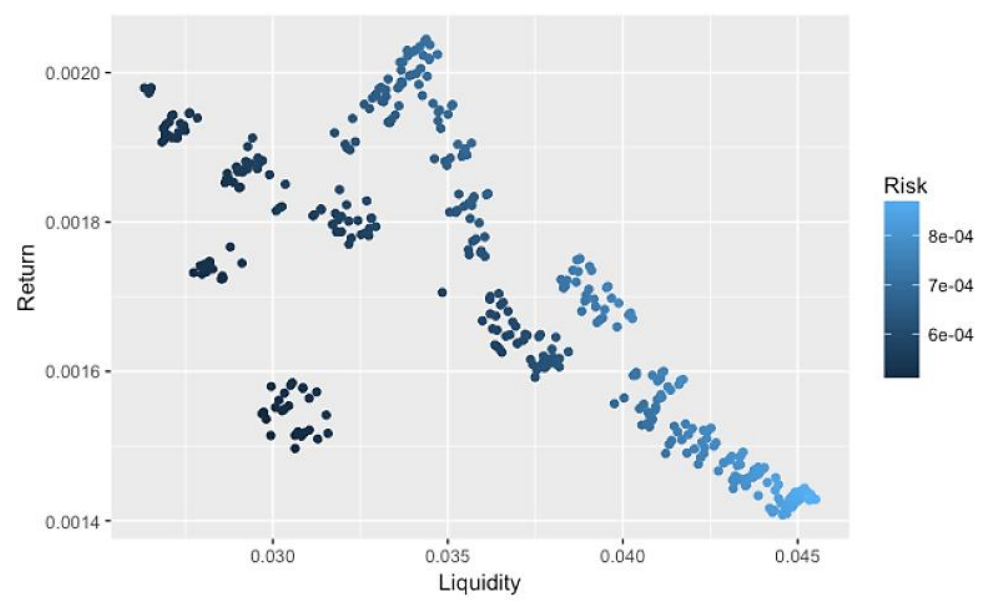

(c) Downside Risk vs. Expected Liquidity

Figure 3. Values of the three corresponding objective functions for all the solutions generatedby NSGA-II 


\section{ENTREPRENEURSHIP AND SUSTAINABILITY ISSUES}

ISSN 2345-0282 (online) http://jssidoi.org/jesi/

2020 Volume 8 Number 2 (December)

http://doi.org/10.9770/jesi.2020.8.2(62)

Make your research more visible, join the Twitter account of ENTREPRENEURSHIP AND SUSTAINABILITY ISSUES: @Entrepr69728810

Table 3. Spearman's rank partial correlation matrix

\begin{tabular}{|c|c|c|c|}
\cline { 2 - 4 } \multicolumn{1}{c|}{} & Return & Risk & Liquidity \\
\hline Return & 1.000 & & \\
\hline Risk & $0.660 * *$ & 1.000 & \\
\hline Liquidity & $-0.811^{* *}$ & $0.940 * *$ & 1.000 \\
\hline
\end{tabular}

Note: ** Correlation is significant at the 0.01 level

This relationship between liquidity and risk can be explained by the fact that more liquid assets are traded more often and therefore are subject to more volatility, increasing their risk. Regarding the liquidity-return correlation, the result suggests that companies which are traded more often are not so profitable than those with less trades.

This paper has proposed a multiobjective approach to portfolio optimization considering return, risk and liquidity. In any given real-world investment scenario, an investor needs to pick a portfolio along the Pareto optimal front Fig. 3 that meets his/her preferences. In order to select the optimal portfolio, this study uses the Sortino ratio, which gauges the risk-adjusted return of an investment asset or portfolio. The Sortino ratio in a credibilistic environment is computed as:

$$
\text { Sortino Ratio }=\frac{E\left(\xi_{p}\right)-E\left(\xi_{R f}\right)}{S V\left(\xi_{p}\right)}
$$

where, $\mathrm{E}\left(\xi_{\mathrm{p}}\right)$ is the expected fuzzy return of the portfolio, $\mathrm{SV}\left(\xi_{\mathrm{p}}\right)$ is the fuzzy semivariance, and $\mathrm{E}\left(\xi_{\mathrm{Rf}}\right)$ is the target or required rate of return, that is, the US 1-Year Treasury Constant Maturity Rate.

Table 4. ETF versus optimal portfolio selected

\begin{tabular}{|c|c|c|c|}
\cline { 2 - 4 } \multicolumn{1}{c|}{} & VaR & Return & Liquidity \\
\hline ETF MILA TRC & 0.2920 & 0.0488 & 0.0167 \\
\hline Optimal Portfolio & 0.2150 & 0.0651 & 0.0327 \\
\hline
\end{tabular}

Finally, it is convenient to compare the performance of the optimal portfolio resulting from the MCMSL model proposed with the performance of a similar investment alternative in the market. Table 4 compares the optimal portfolio selected using the proposed Sortino ratio with its benchmark, the ETF MILA TRC, which tracks the MILA market. Table 4 shows that the selected portfolio beats the benchmark regarding the three selected criteria, return, risk and liquidity. Thereupon, it is confirmed that the applied multiobjective portfolio selection model offers promising results for investors seeking additional goals beyond the return-risk optimization.

\section{Conclusions}

This paper extends the stochastic mean-semivariance model to a credibilistic multiobjective model in which return, risk and liquidity are employed to measure portfolio performance. In order to quantify the uncertainty of the future returns and the liquidity of each risky asset, this study proposes to use L-R power fuzzy numbers, where its membership function is build using the sample percentiles of the historical data set of the returns and liquidity, respectively. Non-dominated Sorting Genetic Algorithm II (NSGA-II) is applied to select efficient portfolios in the fuzzy return-risk-liquidity trade-off in the presence of cardinality constraint and upper and lower bound constraints. To illustrate the usefulness of the proposed model and the solution approach for the multiobjective 


\section{ENTREPRENEURSHIP AND SUSTAINABILITY ISSUES}

ISSN 2345-0282 (online) http://jssidoi.org/jesi/

2020 Volume 8 Number 2 (December)

http://doi.org/10.9770/jesi.2020.8.2(62)

Make your research more visible, join the Twitter account of ENTREPRENEURSHIP AND SUSTAINABILITY ISSUES: @Entrepr69728810

portfolio selection, this paper presents a real-world empirical study using a data set extracted from the Latin American Integrated Market MILA. The computational results of the numerical experiments establish that the proposed MCMSL model supplies sets of efficient portfolios uniformly distributed over the Pareto optimal front, which provide the investor a true picture of trade-offs. Additionally, by maximizing the Sortino ratio for the first time in a credibilistic environment, this study selects the optimum investment weights in a portfolio, and analyzes its performance in relation to another alternative investment during a period of one year.

Based on the fuzzy set theory, this research developed a novel approach by employing a distinctive returnsemivariance-liquidity measure to gauge the portfolio performance in Latin American emerging financial markets. In view of the above discussions, this study concludes that the proposed model provides decision-makers with an effective and practicable alternative to solve the portfolio selection problem.

\section{References}

Arenas-Parra, M., Bilbao-Terol, A., \& Rodríguez-Uría, M. V. (2001). A fuzzy goal programming approach to portfolio selection. European Journal of Operational Research, 133(2), 287-297. https://doi.org/10.1016/S0377-2217(00)00298-8

Arribas, I., García, F., Guijarro, F., Oliver, J., \& Tamošiūnienė, R. (2016). Mass appraisal of residential real estate using multilevel modelling. International Journal of Strategic Property Management, 20(1), 77-87. https://doi.org/10.3846/1648715X.2015.1134702

Aznar, J., \& Guijarro, F. (2016). Housing valuation in Spain. Homogenization method and alternative methodologies. Finance, Markets and Valuation, 2(1), 91-125.

Bawa, V. S. (1975). Optimal rules for ordering uncertain prospects. Journal of Financial Economics, 2(1), 95-121. https://doi.org/10.1016/0304-405X(75)90025-2

Bermúdez, J. D., Segura, J. V., \& Vercher, E. (2012). A multi-objective genetic algorithm for cardinality constrained fuzzy portfolio selection. Fuzzy Sets and Systems, 188(1), 16-26. https://doi.org/10.1016/i.fss.2011.05.013

Carlsson, C., Fullér, R., \& Majlender, P. (2002). A possibilistic approach to selecting portfolios with highest utility score. Fuzzy Sets and Systems, 131(1), 13-21. https://doi.org/10.1016/S0165-0114(01)00251-2

Čižo, E., Lavrinenko, O., Ignatjeva, S. (2020). Analysis of the relationship between financial development and economic growth in the EU countries. Insights into Regional Development, 2(3), 645-660. https://doi.org/10.9770/IRD.2020.2.3(3)

Deb, K., Agrawal, K., Pratap, A., \& Meyarivan, T. (2002). A Fast Elitist Non-dominated Sorting Genetic Algorithm for Multi-objective Optimization: NSGA-II. IEEE Transactions on Evolutionary Computation, 6(2), 182-197. https://doi.org/10.1109/4235.996017

Dubois, D. J., \& Prade, H. (1980). Fuzzy sets and systems: theory and applications (Vol 144). Academic Press.

Fishburn, P. C. (1977). Mean-Risk Analysis with Risk Associated with Below-Target Returns. The American Economic Review, 67(2), 116-126. https://doi.org/10.2307/1807225

García, F., González-Bueno, J., \& Oliver, J. (2015). Mean-variance investment strategy applied in emerging financial markets: Evidence from the Colombian stock market. Intellectual Economics, 9(1), 22-29. https://doi.org/10.1016/J.INTELE.2015.09.003

García, F., González-Bueno, J., Oliver, J., \& Riley, N. (2019). Selecting Socially Responsible Portfolios: A Fuzzy Multicriteria Approach. Sustainability, 11(9, 2496). https://doi.org/10.3390/su11092496

García, F., González-Bueno, J., Oliver, J., \& Tamošiūnienè, R. (2019). A credibilistic mean-semivariance-PER portfolio selection model for Latin America. Journal of Business Economics and Management, 20(2), 225-243. https://doi.org/10.3846/jbem.2019.8317 


\section{ENTREPRENEURSHIP AND SUSTAINABILITY ISSUES}

ISSN 2345-0282 (online) http://jssidoi.org/jesi/

2020 Volume 8 Number 2 (December)

http://doi.org/10.9770/jesi.2020.8.2(62)

Make your research more visible, join the Twitter account of ENTREPRENEURSHIP AND SUSTAINABILITY ISSUES: @Entrepr69728810

García, F., Guijarro, F., \& Moya, I. (2013). A multiobjective model for passive portfolio management: an application on the S\&P 100 index. Journal of Business Economics and Management, 14(4), 758-775. https://doi.org/10.3846/16111699.2012.668859

García, F., Guijarro, F., Oliver, J., \& Tamošiūnienè, R. (2018). Hybrid fuzzy neural network to predict price direction in the german DAX30 index. Technological and Economic Development of Economy, 24(6), 2161-2178. https://doi.org/10.3846/tede.2018.6394

González-Bueno, J. (2019). Optimización multiobjetivo para la selección de carteras a la luz de la teoría de la credibilidad. Una aplicación en el mercado integrado latinoamericano. Editorial Universidad Pontificia Bolivariana.

Guijarro, F. (2015). Multicriteria ranking of the Spanish digital press. Finance, Markets and Valuation, 1(1), 51-65.

Gupta, P., Inuiguchi, M., \& Mehlawat, M. K. (2011). A hybrid approach for constructing suitable and optimal portfolios. Expert Systems with Applications, 38(5), 5620-5632. https://doi.org/10.1016/j.eswa.2010.10.073

Gupta, P., Inuiguchi, M., Mehlawat, M. K., \& Mittal, G. (2013). Multiobjective credibilistic portfolio selection model with fuzzy chanceconstraints. Information Sciences, 229, 1-17. https://doi.org/10.1016/j.ins.2012.12.011

Gupta, P., Mehlawat, M. K., Inuiguchi, M., \& Chandra, S. (2014). Portfolio Optimization with Interval Coefficients. In Fuzzy Portfolio Optimization. Studies in Fuzziness and Soft Computing (Vol 316, pp. 33-59). Springer, Berlin, Heidelberg. https://doi.org/10.1007/978-3$\underline{642-54652-5 \_2}$

Gupta, P., Mehlawat, M. K., \& Saxena, A. (2008). Asset portfolio optimization using fuzzy mathematical programming. Information Sciences, 178(6), 1734-1755. https://doi.org/10.1016/j.ins.2007.10.025

Gupta, P., Mehlawat, M. K., \& Saxena, A. (2010). A hybrid approach to asset allocation with simultaneous consideration of suitability and optimality. Information Sciences, 180(11), 2264-2285. https://doi.org/10.1016/J.INS.2010.02.007

Gupta, P., Mittal, G., \& Mehlawat, M. K. (2013). Expected value multiobjective portfolio rebalancing model with fuzzy parameters. Insurance: Mathematics and Economics, 52(2), 190-203. https://doi.org/10.1016/j.insmatheco.2012.12.002

Huang, X. (2006a). Fuzzy chance-constrained portfolio selection. Applied Mathematics and Computation, 177(2), 500-507. https://doi.org/10.1016/j.amc.2005.11.027

Huang, X. (2008). Mean-semivariance models for fuzzy portfolio selection. Journal of Computational and Applied Mathematics, 217(1), 1-8. https://doi.org/10.1016/j.cam.2007.06.009

Huang, X. (2009). A review of credibilistic portfolio selection. Fuzzy Optimization and Decision Making, 8(3), $263-281$. https://doi.org/10.1007/s10700-009-9064-3

Huang, X. (2010). Portfolio Analysis, From Probabilistic to Credibilistic and Uncertain Approaches (Vol. 250). Springer Berlin Heidelberg. https://doi.org/10.1007/978-3-642-11214-0

Huang, X. (2006b). Credibility based fuzzy portfolio selection. IEEE International Conference on Fuzzy Systems, 159-163. https://doi.org/10.1109/FUZZY.2006.1681709

J.P.Morgan. (1996). Riskmetrics technical document (4th ed.). Morgan Guaranty Trust Company of New York.

Jalota, H., Thakur, M., \& Mittal, G. (2017a). Modelling and constructing membership function for uncertain portfolio parameters: A credibilistic framework. Expert Systems with Applications, 71, 40-56. https://doi.org/10.1016/j.eswa.2016.11.014

Jalota, H., Thakur, M., \& Mittal, G. (2017b). A credibilistic decision support system for portfolio optimization. Applied Soft Computing, 59, 512-528. https://doi.org/10.1016/j.asoc.2017.05.054

Li, X., \& Qin, Z. (2014). Interval portfolio selection models within the framework of uncertainty theory. Economic Modelling, 41, 338344. https://doi.org/10.1016/j.econmod.2014.05.036 


\section{ENTREPRENEURSHIP AND SUSTAINABILITY ISSUES}

ISSN 2345-0282 (online) http://jssidoi.org/jesi/

2020 Volume 8 Number 2 (December)

http://doi.org/10.9770/jesi.2020.8.2(62)

Make your research more visible, join the Twitter account of ENTREPRENEURSHIP AND SUSTAINABILITY ISSUES: @Entrepr69728810

Liagkouras, K., \& Metaxiotis, K. (2015). Efficient Portfolio Construction with the Use of Multiobjective Evolutionary Algorithms: Best Practices and Performance Metrics. International Journal of Information Technology \& Decision Making, 14(03), 535-564. https://doi.org/10.1142/S0219622015300013

Liu, B. (2004). Uncertainty theory: an introduction to its axiomatic foundations (Vol 154). Springer-Verlag Berlin Heidelberg.

Liu, B. (2007). Uncertainty Theory an Introduction to its Axiomatic Foundations (2nd ed.). Springer-Verlag Berlin Heidelberg.

Liu, B., \& Liu, Y. K. (2002). Expected value of fuzzy variable and fuzzy expected value models. IEEE Transactions on Fuzzy Systems, 10(4), 445-450. https://doi.org/10.1109/TFUZZ.2002.800692

Liu, J., Jin, X., Wang, T., \& Yuan, Y. (2015). Robust multi-period portfolio model based on prospect theory and ALMV-PSO algorithm. Expert Systems with Applications, 42(20), 7252-7262. https://doi.org/10.1016/J.ESWA.2015.04.063

Markowitz, H. (1952). Portfolio Selection. The Journal of Finance, 7(1), 77-91. https://doi.org/10.1111/j.1540-6261.1952.tb01525.x

Markowitz, H. (1959). Portfolio selection: efficient diversification of investments. Jhon Wiley \& Sons, Inc.

Markowitz, H., Todd, P., Xu, G., \& Yamane, Y. (1993). Computation of mean-semivariance efficient sets by the Critical Line Algorithm. Annals of Operations Research, 45(1), 307-317. https://doi.org/10.1007/BF02282055

Masood, O., Tvaronavičienė, M., \& Javaria, K. (2019). Impact of oil prices on stock return: evidence from G7 countries. Insights into Regional Development, 1(2), 129-137. https://doi.org/10.9770/ird.2019.1.2(4)

Mehlawat, M. K. (2016). Credibilistic mean-entropy models for multi-period portfolio selection with multi-choice aspiration levels. Information Sciences, 345, 9-26. https://doi.org/10.1016/j.ins.2016.01.042

Palanikumar, K., Latha, B., Senthilkumar, V. S., \& Karthikeyan, R. (2009). Multiple performance optimization in machining of GFRP composites by a PCD tool using non-dominated sorting genetic algorithm (NSGA-II). Metals and Materials International, 15(2), 249258. https://doi.org/10.1007/s12540-009-0249-7

Ren, F., Lu, Y.-N., Li, S.-P., Jiang, X.-F., Zhong, L.-X., \& Qiu, T. (2017). Dynamic Portfolio Strategy Using Clustering Approach. PLOS ONE, 12(1), e0169299. https://doi.org/10.1371/journal.pone.0169299

Rockafellar, R. T., \& Uryasev, S. (2000). Optimization of conditional value-at-risk. Journal of Risk, 2(3), 21-41.

Rockafellar, R. T., \& Uryasev, S. (2002). Conditional value-at-risk for general loss distributions. Journal of Banking \& Finance, 26(7), 1443-1471. https://doi.org/10.1016/S0378-4266(02)00271-6

Saborido, R., Ruiz, A. B., Bermúdez, J. D., Vercher, E., \& Luque, M. (2016). Evolutionary multi-objective optimization algorithms for fuzzy portfolio selection. Applied Soft Computing, 39, 48-63. https://doi.org/10.1016/j.asoc.2015.11.005

Sortino, F. A., \& Price, L. N. (1994). Performance Measurement in a Downside Risk Framework. The Journal of Investing, 3(3), 59-64. https://doi.org/10.3905/joi.3.3.59

Speranza, M. (1993). Linear programming models for portfolio optimization. Finance, 14, 107-123.

Vercher, E. (2008). Portfolios with fuzzy returns: Selection strategies based on semi-infinite programming. Journal of Computational and Applied Mathematics, 217(2), 381-393. https://doi.org/10.1016/j.cam.2007.02.017

Vercher, E., \& Bermúdez, J. D. (2012). Fuzzy Portfolio Selection Models: A Numerical Study. In M. Doumpos, C. Zopounidis, \& P. M. Pardalos (Eds.), Financial Decision Making Using Computational Intelligence. Springer Optimization and Its Applications (Volumen 70, pp. 253-280). Springer, Boston, MA. https://doi.org/10.1007/978-1-4614-3773-4_10

Vercher, E., \& Bermúdez, J. D. (2013). A Possibilistic Mean-Downside Risk-Skewness Model for Efficient Portfolio Selection. IEEE Transactions on Fuzzy Systems, 21(3), 585-595. https://doi.org/10.1109/TFUZZ.2012.2227487 


\section{ENTREPRENEURSHIP AND SUSTAINABILITY ISSUES}

ISSN 2345-0282 (online) http://jssidoi.org/jesi/

2020 Volume 8 Number 2 (December)

http://doi.org/10.9770/jesi.2020.8.2(62)

Make your research more visible, join the Twitter account of ENTREPRENEURSHIP AND SUSTAINABILITY ISSUES: @Entrepr69728810

Vercher, E., \& Bermúdez, J. D. (2015). Portfolio optimization using a credibility mean-absolute semi-deviation model. Expert Systems with Applications, 42(20), 7121-7131. https://doi.org/10.1016/j.eswa.2015.05.020

Vercher, E., Bermúdez, J. D., \& Segura, J. V. (2007). Fuzzy portfolio optimization under downside risk measures. Fuzzy Sets and Systems, 158(7), 769-782. https://doi.org/10.1016/i.fss.2006.10.026

Wang, S., \& Zhu, S. (2002). On Fuzzy Portfolio Selection Problems. Fuzzy Optimization and Decision Making, 1(4), 361-377. https://doi.org/10.1023/A:1020907229361

Zadeh, L. A. (1965). Fuzzy sets. Information and Control, 8(3), 338-353. https://doi.org/10.1016/S0019-9958(65)90241-X

Fernando GARCÍA received the B.S. degree from the Hochschule Bremen, in Germany in 1998, the M.S. degree in Business Administration from the Universitat de València, Valencia, Spain, in 1999, and the Ph.D. degree from the Universitat Politecnica de Valencia in 2005. He is associate professor of finance in the Business School of Universitat Politècnica de València. His research interests include investment strategies, multicriteria decision making, corporate responsibility and asset valuation. He has published more than 30 papers in indexed Journals such as Technological and Economic Development of Economy, Mathematical and Computer Modelling, Journal of the Operational Research Society, Journal of Business Economics and Management, Sustainability, Computers and Operations Research, Journal of Environmental Management, Neural Computing and Applications, among others. He is an Associate Editor of the journals Entrepreneurship and Sustainability Issues; Finance, Markets and Valuation; and Insights into Regional Development.

ORCID ID: https://orcid.org/0000-0001-6364-520X

Jairo. GONZÁLEZ-BUENO received the B.S. degree in financial engineering from the Universidad Autónoma de Bucaramanga, Colombia, in 2004, the M.S. degree in business administration from Universidad Industrial de Santander, Colombia, in 2012, and the Ph.D. in business management and administration from Universitat Politècnica de València, Spain, in 2018. He is currently an associate professor of finance with the faculty of business administration, Universidad Pontificia Bolivariana, Colombia. His current research interests include portfolio management, finance ethics and valuation. His research has been published in Journal of Business Economics and Management, Sustainability, and Journal Finance, Markets and Valuation, among others.

ORCID ID: https://orcid.org/0000-0002-5896-094X

Francisco GUIJARRO received the B.S. degree in computer science from Universitat Politècnica de València, Valencia, Spain, in 1998, the Ph.D. degree from the same University in 2003, and the M.S. degree in Statistics from Universitat de València, Valencia, Spain, in 2007. He is professor of finance in the Business School of Universitat Politècnica de València. His research interests include portfolio management, trading strategies and multicriteria decision models. He has published more than 30 papers in indexed Journals such as Expert Systems with Applications, European Journal of Operational Research, Journal of the Operational Research Society, Annals of Operations Research, Sustainability, Computers and Operations Research, International Transactions in Operational Research, among others. He has also served as editor in different Special Issues.

ORCID ID: https://orcid.org/0000-0002-8803-5165

Javier OLIVER was born in Valencia, Spain in 1973. He received the Bachelor degree in Business Administration from the Universitat de València in 1996, Master degree in Finance from Universitat Politècnica de València in 2010 and the Ph.D. degree in Business Administration from the Universitat Politècnica de València in 2014. Since 2011 to the present, he is an Associate Lecturer on the Economics Analysis Department in the Universitat de València. As well, since 2013 to the present he serves as Associate Lecturer in the Economics and Social Sciences Department of the Universitat Politècnica de València. He has co-authored several articles in the financial area.

ORCID ID: https://orcid.org/0000-0001-5317-6489 
ENTREPRENEURSHIP AND SUSTAINABILITY ISSUES

ISSN 2345-0282 (online) http://jssidoi.org/jesi/

2020 Volume 8 Number 2 (December)

http://doi.org/10.9770/jesi.2020.8.2(62)

Make your research more visible, join the Twitter account of ENTREPRENEURSHIP AND SUSTAINABILITY ISSUES: @Entrepr69728810

Register for an ORCID ID:

https://orcid.org/register

Copyright (C) 2020 by author(s) and VsI Entrepreneurship and Sustainability Center

This work is licensed under the Creative Commons Attribution International License (CC BY).

http://creativecommons.org/licenses/by/4.0/

(c) (i) Open Access 